\title{
Perception Of Female Communication Graduates Towards Choosing A Profession In Print Journalism Field: A Case Study
}

\author{
Jayawardhana.K.G.L.A.N.S.* and Sriram. S.** \\ *Senior Lecturer in Communication Studies, \\ Department of Languages and Communication Studies, \\ Trincomalee Campus of Eastern University, Sri Lanka. \\ And \\ **Senior Lecturer in Communication Studies, \\ Department of Languages and Communication Studies, \\ Trincomalee Campus of Eastern University, Sri Lanka. \\ DOI: 10.29322/IJSRP.11.11.2021.p11924 \\ http://dx.doi.org/10.29322/IJSRP.11.11.2021.p11924
}

\begin{abstract}
Journalism and/or mass communication has been expanded as an academic discipline in many Sri Lankan state and private universities, and when carefully observed it is apparent that very less number of female graduates finds their career path in the print journalism field. In Sri Lanka, a majority of the prominent characters in the newspaper industry are men, whereas the role of women journalists is always a question. Hence, this study was conducted to find out the reasons for female media graduates to choose their profession as journalists in print media and to find out the reasons for female graduates to deny choosing their profession as print media journalists. As per the responses received from 60 females graduated with BA in Communication Studies degree at the Department of Languages and Communication Studies, Trincomalee Campus, Eastern University, presently, only $4 \%$ of the respondents work as journalists in print media and majority of female graduates (57\%) involved in other professions while $36 \%$ is unemployed. The data further indicates that $42 \%$ of the respondents are not interested in working in the print media due to the pressure of the heavy work load (24\%), less freedom (16\%), low salary (16\%), lack of reputation or recognition (16\%), personal dislikes towards newspaper industry (16\%) and family restrictions (12\%). As per the findings, $80 \%$ of the female respondents are interested to work in electronic media mainly due to their passion to work in a television/ radio station. Finally, the respondents recommended that strengthening and encouraging the female students to join the newspaper industry, designing the print media courses including more practical components, and increasing the salary of print media professionals in Sri Lanka would increase the female participation in print journalism.
\end{abstract}

Index Terms: Print media, Female students, communication degree, journalists

\section{I.INTRODUCTION}

'Human's desire to know' has been identified as one of the most potent forces in his/her survival and advancement. A great part of the story of communication and information evolution represents the newspaper press which in the course of its development, reached a point where it was able to bring full and prompt reports to people from different continents of the world. Newspaper press was able to progressively broaden the horizons of all people, giving them opportunity to acquaint themselves with other lands and people.

Newspapers are traditional methods of getting information. Newspapers contain news, other informative articles and usually advertising. A newspaper is printed on relatively inexpensive, low-grade paper such as newsprint. The news organizations that publish newspapers are themselves often metonymically called newspapers (Syed, 2002). 
A wide variety of subjects has been covered and published in newspapers, such as weather forecasts; criticism and reviews of the arts (including literature, film, television, theater, fine arts, and architecture) and of local services such as restaurants, obituaries, entertainment features such as crosswords, horoscopes, editorial cartoons, gag cartoons and comic strips, advice, food, and other columns; and radio and television listings.

\section{Newspapers in Sri Lanka}

It was the time when Sir. William Colebrook's visit to Sri Lanka to study and report on administrative, financial, economic and judicial reforms in 1829 and he stressed that the non-existence of independent newspapers was the main cause for the excessive powers of the governors.

\section{English Newspapers in Sri Lanka}

Under the auspices and with the encouragement of the British government, "Colombo Journal" was published on 01 ${ }^{\text {st }}$ January 1832 . It was printed at the government press, edited by George Lee, its superintendent, and Henry Tufnell was appointed as the Assistant Director. Then, a series of newspapers came to the platform such as, "The Observer and Commercial Advertiser", "Ceylon Chronicle", "Ceylon Advertiser and General Intelligent", "Kandy Herald", "Jaffna Freeman", and "Ceylon Independent". It is obvious that all of the pioneers of the newspaper industry in Sri Lanka are men. George Winter was the Editor for "The Observer and Commercial Advertiser" newspaper. Richard Morgar was regular contributor to "Kandy Herald" Newspaper. The first editor of Ceylon Independent newspaper also was George Wall. In "Morning Leader", Charles Pieris, Sir James Pieris and Mr. W.A.De Silva contributed a lot. D.R Wijewardene too played a significant role in the newspaper Industry in Sri Lanka. Except these newspapers there are some other English newspapers such as, "Ceylon Daily News" (1918), "Ceylon Observer" (1923), "Jaffna Catholic Guardian”(1894-1949), “Sun” (1964-1990), "Hindu Organ” (1900-1949), “Weekend” (1965-1984), "Ceylon Daily Mirror" (19611979), "Weekend Express" (1966), “Sunday Leader" (1993), "Island”(1981), "Sunday Island" (1991), and "Sunday Times" (1993).

\section{Sinhala Newspapers}

The first Sinhala Newspaper in the country was "Lanka Loka" published at Gall in June 1860. It was published twice a month by W.E.Eaton. "Lakmini Pahana" was published on $17^{\text {th }}$ September 1862, pioneered by Koggala Pandit or Jahannes."Lakrivikirana", "Dinapatha Pravurthi", "Lanka Pradeepaya", "Kawata Kathikaya", "Sarasavi Sanderesa", "Swarajjaya", "Satbasa", "Lakmina" (1913), "Dinakara Prakasha" (1915), "Sinhala Samaja" (1903), "Sinhala Jathiya" (1901), "Sinhala Bauddhaya", "Dinamina" (1909), and "Swadeshamithraya" (1924) are some of the other Sinhala newspapers that opened new avenues for the people to make aware of and share the knowledge.

\section{Tamil Newspapers}

"Uthaya Thaarakai" (1841), “Uthayaathiththan" (1844), "Ilangai Nesan” (1848), "Ilangabimaani" (1863), "PalliyaNesan" (1865), "Catholica Paathukavalan" (1876), "UdayaBanu” (1880), "Muslim Nesan” (1882), "Indhu Saathanam" (1889), "Ezhakesari” (1930), "Virakesari”(1930), "Thinakaran"(1932), "Uthayan" (1985), "Thinakkural" (1997), "Sudar Oli" (2000) are some of the Tamil newspapers which were published in early Sri Lanka. During the 20th century, "Thinakaran", "Thinakural", "Veerakesari" Tamil newspapers were in circulation.

The history about the birth and development of the newspaper in Sri Lanka clearly shows that, Sri Lanka has been a pioneering country in Asia publishing newspapers in the early nineteenth century maintaining some of the same newspapers even by today. It has been encouraged the publication of the various types of newspapers in three languages (Sinhala, Tamil and English), which was helpful in molding the public opinion of the country and establishing the democratic principles of a free press in a developing country.

\section{Men and Women Journalists}

Both men and women work as journalists in the newspaper industry in Sri Lanka. But men journalists play a pioneering role in newspaper journalism, whereas the role of women in newspaper industry is always a question. The number of women journalists who work in Sri Lankan Newspaper industry is handful. The influence of women in journalism is one of the problematic areas in feminist media research. According to a survey which was done by the International Federation of Journalism Media and Gender in AsiaPacific Research Project (2015), the survey indicated that journalists in Sri Lanka are well educated. More men had undergraduate degrees $(48.48 \%)$ compared with women who only possessed $26.66 \%$. However, more women had postgraduate qualifications 
(24.44\%) compared with men (12.12\%). Nearly half of all respondents had professional qualifications, such as diplomas and certificates $(46.66 \%$ of women and $45.45 \%$ of men). A quarter of all respondents had attained at least their secondary school certificate as their highest level of education.

\section{Availability of Media Education in Sri Lanka}

The media education in Sri Lanka has been started in the year 1968. The first Journalism course was offered at Dehiwela Junior Campus during the year 1968-1969. The curriculum of this course was designed by the veteran journalist, Dr. Edwin Aariyadasa. Later in the year 1973, communication studies have been expanded as an academic discipline and a degree programme at the University of Kelaniya under the name of Mass Communication studies. Meantime, a new diploma course in Journalism was introduced at the University of Sri Jayawardhanapura in the year 1972.

Professor K. Kailasapathy and Professor K.Sivaththamby jointly introduced "Journalism" as a subject in the Bachelor of Arts in Tamil degree programme at the University of Jaffna. In addition to these universities, the professional training courses were conducted by the Sri Lanka Broadcasting Corporation and Lakehouse in the year 1960's. Eventually, the study of journalism and or mass communication was introduced as an academic discipline and as a degree programme in many of the Sri Lankan state and private universities.

In addition, currently, the College of Journalism, Sri Lanka Foundation, Sri Lanka Development Journalists Forum, Sri Lanka Media Training Institute and many other institutes provide professional courses on journalism and provide hands on practical training on journalism in Sri Lanka. As such, the students who are willing to follow a course on journalism and or mass communication have more avenues in contemporary Sri Lanka.

\section{Problem Statement}

In a university which offers a degree in media, it is the intention of the system to produce a well-educated media personality who can contribute more to the society than other journalists who come to the field without having a proper and related educational background.

It is apparent from the data, that the majority of the students who follow their degree programmes on communication/ mass communication/ mass media at Trincomalee Campus, University of Kelaniya, Sri Palee Campus, University of Sri Jayawardhanapura and University of Jaffna are female over male. When carefully observed, it is understandable that very less number of female students finds their path in the journalism field, especially in the print journalism. Number of women journalists in Sri Lanka has increased their active participation as journalists and several women, particularly in the English language media, hold senior positions. However, considerable number of female students can be seen in the television journalism field, but it is rare to find their presence in the print media industry today.

Thus, there's a necessity to find out, whether female media graduates choose their profession as journalists in the print media and if so, what are the reasons for that and whether female graduates deny choosing their profession as journalists in the print media, if so what are the reasons that. Significantly, the findings of the study pave the path to modify the course syllabus accordingly.

\section{Research Questions}

a. Do female media students choose their profession as journalists in the print media and if so, what are the reasons?

b. Do female students deny choosing their profession as journalists in the print media; if so what are the reasons?

\section{Research Objectives}

a. To find out whether female media students choose their profession as journalists in the print media and if so, to find out the reasons for that.

b. To find out whether female students deny choosing their profession as journalists in the print media, if so to find out the reasons for that.

\section{LITERATURE REVIEW}

This publication is licensed under Creative Commons Attribution CC BY. 
When finding out the literature related to the female media graduates and their preference to choose a career related to newspaper journalism field, the researchers could gather more important information especially in the global context.

McAdamas.et.al (2004) have done a study on "Women graduated (and men too) express reservations about journalism education" and the study says that "since the mid-1970s, researchers have established that a gender shift has occurred in journalism education. What was once a male dominated field of study has changed so that, national wide, schools and colleges of journalism of all sizes have found their populations dominated by women since the late 1970s. About two thirds of journalism students were women throughout the 1980s and 1990s, and the trend to feminization in terms of enrollment persists for both graduate and undergraduate students. Until recently, few people have felt this trend worthy of note, but we have thought for the last decade that the ongoing phenomena of the gender shift in journalism education was worthy of further examination".

Jackson.et. all (2020), on their article on "Fantasy, pragmatism, and journalistic socialization: UK journalism students' aspirations and motivations", mentions "despite the sustained growth of journalism as a choice of degree path for young people, our understanding of students' aspirations and motivations remains relatively underdeveloped. At the same time, that journalism careers appear increasingly uncertain, as the industry responds to digitalization and convergence. And their study finds that intrinsic motivations (calling talent, dynamic job) prevail over public service ones, with students drawn to soft news beats over hard news. Aspirations are also strikingly gendered, opening up questions of journalism education in this process. We also find that while students articulate an inspirational career in respected media outlets, they are pragmatic about their immediate career prospects. Here, journalism education appears to play a significant role in socializing students towards careers beyond journalism".

Emmanuel.et. all (2021) have done a study on "Beyond classroom- news room Gap: why do Nigerian students study journalism in the age of convergence", mentions that, "Nigerian Journalism students still found classroom experience valuable as the knowledge and skills acquired therein, assisted them in the discharge of their professional responsibilities during internship. And the same time, journalism students in the country still hold firmly to the traditional conceptualization of journalism, which constricts journalism jobs to radio, television, newspaper and magazine, suggesting a manifest conflict between the idealistic perception of journalism students and what journalism in Nigeria currently portends.

There are number of studies have been done on female media graduates and their preference to choose a career related to newspaper journalism field. But there was no any recent study has been done on Sri Lankan context on female media graduates and their preference to choose a profession related to newspaper journalism field in contrast to men journalists. Thus, this research will be a complimentary study to fill the aforesaid gap.

\section{RESEARCH METHODOLOGY}

Survey research method is one of the most common quantitative research methods used in the field of social science. In this method, the researcher selects a sample of a target population and manages a standardized questionnaire to that sample of target population. The questionnaire, or survey, can be a written document that is completed by the person being surveyed during the research; it should be a telephone interview, a face-to-face interview, social media or an online questionnaire. In the present study, the researchers developed a questionnaire and used it as a tool for the data collection from the target audience.

The samples were selected from the graduated female students belonging to the academic year 2014/2015 (21 students) and 2015/2016 (63 students) who recently completed their BA in Communication Studies degree at the Department of Languages and Communication Studies, Faculty of Communication and Business Studies, Trincomalee Campus, Eastern University, Sri Lanka. Among the 84 total graduates ( 8 male and 76 female), only 60 female students were selected as the sample. This includes 10 students from the academic year 2014/2015 and 50 students from the academic year 2015/2016. To achieve the objectives of this study, a questionnaire was distributed among 60 respondents via emails/WhatsApp and the data analysis was done using SPSS Package.

\section{FINDINGS}

Researchers have issued questionnaires to 60 female respondents and all of them replied. Among them, 48 females were Sinhalese, 10 were Tamils and 02 were Muslims and they are in their age between 24-27 years. Majority of the respondents are unemployed (39\%), and others are teachers (32\%), self-employed (10\%), Tuition teachers (7\%), Lecturers (3\%), Assistant Lecturers (3\%) and Assistant Manager (2\%), Content Writer (2\%) and freelance journalists (2\%). Among the respondents, majority of them (50\%) reside in urban cities (Colombo, Kandy, Kurunegala, Trincomalee, Jaffna), and others reside in sub-urban areas (33\%) and villages (17\%). 
All the respondents are the graduates who followed the degree programme, Bachelor of Arts in Communication Studies at the Department of Languages and Communication Studies, Trincomalee Campus, Eastern University, Sri Lanka, between the period of 2015 - 2021. These respondents have selected the aforementioned degree programme due to three reasons; they are interested in developing their career in the media field (47\%), 33\% of them did not have any specific aims when they choose the particular degree programme and the other reason is, they are interested in becoming a school teacher and to teach communication and media studies subject (20\%).

These female graduates have studied numerous communication studies related subjects during their under graduate period, however, they prefer some specific subjects because of the practical exposures they acquired through them. In this line, respondents are interested to study the subject "Advertising", because the students are interested in creating advertisements and especially print and television advertisements, this subject helped them to develop creative ideas, and to analyze and create advertisements according to the needs and expectations of their audience, thus, it is an interesting subject. Next, they like the subject "Film and Television", because they love film and television field, which is an interesting subject that helps them to identify the practical and technical aspects of film and television productions, the subject were taught interesting way covering the theories and practical on lighting, camera handling, camera movements and shooting, the roles of the production crew were well explained, and the subject is more practical oriented.

The respondents also prefer the subject "Writing for media", because it has stimulated students' interest towards recognizing their writing skills and writing a script. And further, they prefer the subjects "Beginning and Advanced video productions" as the students enjoyed experiences in script writing, shooting and audio video editing, which are more practical oriented, that allowed them to get involved in documentary and short film making.

The respondents also informed that they gained the real working experience through the subject "Journalism Practicum" which gave them the opportunity to see the practical scenario in the media stations. The students worked at media stations and the experiences they gained have strengthened their skills, through training received during their internship. This three month internship experience develops multi-tasking skills in the students.

As per the responses received, "Print Media" is also one of the interesting subjects, because it teaches the process and the techniques behind news writing, news reporting and printing. The subject is more on how to write news articles on social issues, page maker designing and publishing a newspaper by their own, and that made the subject more interesting, students mentioned. Respondents are interested on the subject "Media Ethics", as the subject discusses on ethics that are implemented when reporting news and in different ethical dilemmas.

As per the findings it could be said that, the respondents are interested more on practical subjects over theoretical subjects as they were able to produce different formats of media productions using their creativity and skills. As such, the female respondents are interested in Print Media and they are interested to write news articles, edit them and publish them.

\section{Female graduates' preference towards working as a Journalist in print media}

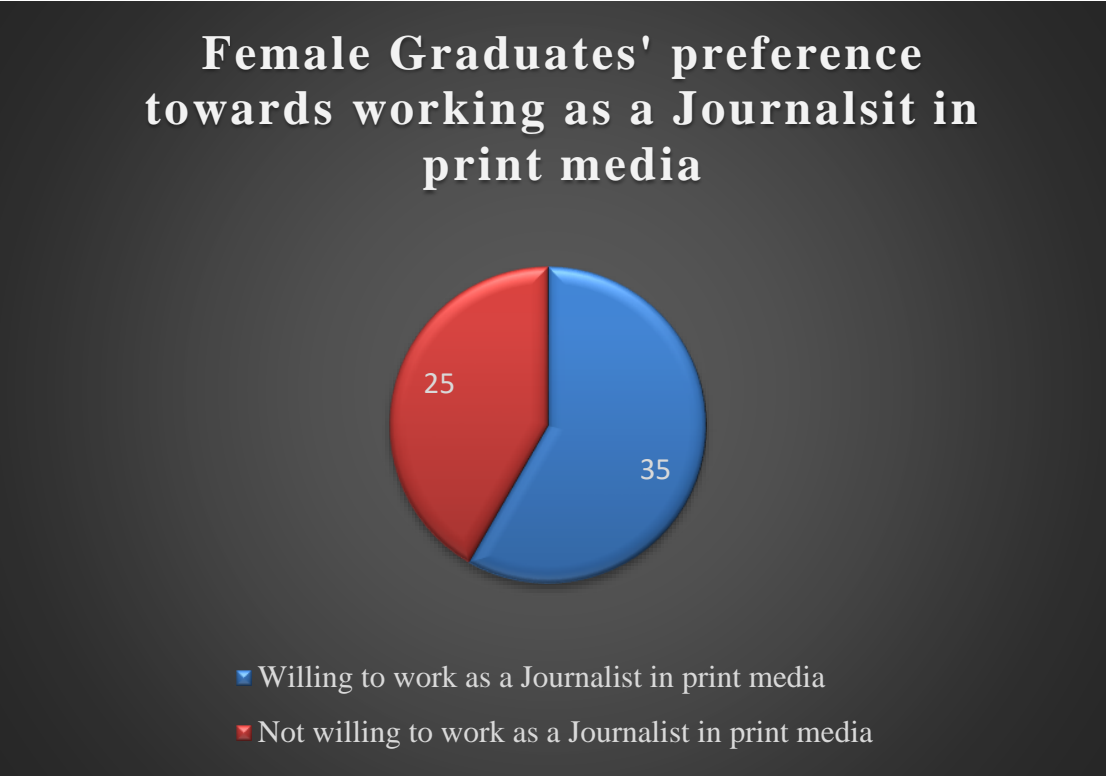


Chart 1: Female graduates' preference towards working as a Journalist in print media

As per the findings, majority $(58 \%)$ of the female respondents said that they are interested in working as a journalist in print media. According to them, they prefer to choose this profession because it is a social service (34\%), it is a profession which enables them to have dynamic experiences (28\%), the passion they have on newspaper journalism (17\%), recognition (9\%), they like to update themselves and gather information $(6 \%)$ and it is a dream from their childhood $(6 \%)$. Based on the findings, it is obvious that almost all the respondents $(100 \%)$ believe that the profession as a journalist in Sri Lankan print media will not give them high financial stability.

When considering the female graduates' present occupations, only $4 \%$ of the all respondents work as journalists in print media (content writer and freelance journalists) and majority (57\%) of other respondents involved in various professions such as government teachers, tuition teachers, self-employed and academics while $36 \%$ are unemployed. So, it could be concluded that, though respondents are interested to work as journalists in print media they have not chosen the profession due to some external reasons that demotivate them.

Further, the data indicates that $42 \%$ of respondents are not interested in working as a journalist in print media. As per their responses, they are not interested because of the pressure they could get due to the heavy work load (24\%), less freedom they receive when working as a journalist in print media (16\%), low salary (16\%), a good reputation or recognition cannot be gained for a newspaper journalist in a country like Sri Lanka (16\%), disliking the newspaper industry, but happy with audio visual media (16\%) and family restrictions imposed upon them $(12 \%)$.

Female graduates' preference towards working in Electronic media (Television and Radio)

\section{Female graduates' preference toward working in Electronic media}

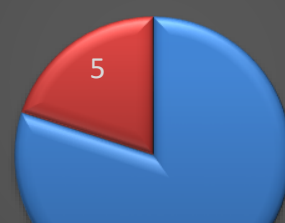


Chart 2: Female graduates' preference towards working in Electronic media

As per the findings, $80 \%$ of the female respondents said that they are interested to work in electronic media. According to their responses, they are interested to work at Television and Radio stations because of their passion on working in a television/ radio station $(50 \%)$, they are happy to be a radio presenter (25\%), they are happy to be known by the people from their appearance (5\%), happy to be a presenter in television (5\%), it is an interesting field (5\%). Being able to take part in various programmes and meet famous people face to face when working in television and or radio station $(5 \%)$ and having sound knowledge in visual production $(5 \%)$.

In contrast, $20 \%$ of the total female respondents had responded that they do not have interest to work in Electronic media because of the family restrictions imposed upon them not allowing them joining a media station as they are females (40\%), they are interested only in print media, not to work in television or radio station (40\%) and $20 \%$ of them prefer working behind the camera.

It is obvious from the findings that, the female respondents prefer to work in print media (35\%) over electronic media (20\%), nevertheless, the data indicates that only few of them are currently working at newspaper industry as many external factors have stopped female media graduates being occupied in journalism field.

\section{Recommendations to improve women's participation in newspaper industry in Sri Lanka}

The data point out certain recommendations to improve the participation of women in Sri Lankan newspaper industry. The following suggestions were recommended by the respondents. Female media students should be strengthen and encouraged to join the newspaper industry which is considered as a male dominated industry in Sri Lanka (50\%), universities which offer print media courses should design and teach Print media subject more interestingly and should include more practical aspects to the subject (25\%), increasing the salary of media professionals in Sri Lanka (11\%), maintaining professionalism in print media (2\%), giving the due recognition and reputation to newspaper Journalists, especially to female journalists (2\%), everyone's skills should be treated equally regardless of their gender $(2 \%)$, availability of standard training institutions on newspaper journalism for those who are passionate about improving their skills and working in newspaper industry (2\%), providing short term training to those who already work at newspaper industry (2\%), minimizing the political interference and ensuring the freedom of the press (2\%) and the societal myths such as media is not a safe place for women should be removed (2\%). As per the respondents, these recommendations would increase the participation of women graduates in the newspaper industry in Sri Lanka.

\section{CONCLUSIONS}

The study concludes that the female respondents are interested in finding their career in the media field and settling down there. Majority of the respondents have chosen the Communication Studies degree course as they are interested in becoming a school teacher to teach communication and media studies subject. Female graduates are interested more on practical subjects over theoretical subjects in the field of Communication and Media Studies as they were able to produce audio/video and visual productions using their creative and technical skills. As such, the female respondents are interested in print media especially when it comes to writing news articles, editing them and publishing them.

The study concludes that the female graduates prefer working as Journalists in print media than working in Electronic media. However, they do not choose this profession because of the heavy work load, less freedom they get when working as a Journalist in print media, low salary, lack of reputation or recognition a newspaper journalist has in a country like Sri Lanka and some female students personally dislike newspaper industry, instead they prefer audio visual media.

Concluding the study, it was highlighted by the respondents that the academics, politicians, and the society should take the required steps to decrease certain conditions which blocks or impedes women graduates from choosing their profession as a Journalist in Sri Lanka, and encouraging the female students to join the newspaper industry which is considered as a male dominated industry in Sri Lanka. Universities which offer print media courses should design and teach the print media subject more interestingly including more practical aspects into the subject. And increasing the salary of print media professionals in Sri Lanka and maintaining professionalism in print media, would give the due recognition and reputation to newspaper journalists, in an environment where skills should not be specialized based on gender. Both males and females should be treated equally, if anyone is passionate about working at newspaper industry he or she should be allowed to improve their skills and for that, there should be places to offer trainings on newspaper journalism, providing short term training to those who work at newspaper industry. Minimizing the political 
interference and allowing the freedom of the press would motivate the female media graduates considerably and the societal myths such as media is not a safe place for women should be removed.

\section{REFERENCES}

[1] Amparo López-Meri, Laura Alonso-Muñoz \& Andreu Casero-Ripollés (2021) What is Behind the Entrepreneurship Intention in Typologies Based on Student Perceptions, Journalism Practice, 15:3, 402-419, DOI: 10.1080/17512786.2020.1715821

[2] Coleman.R, Lee.Y.J, Yaschur.C, Meader.A.P, McElroy.K (2018) Why be a journalist/ US students' motivations and role conceptions in the new age of journalism, Journalism 19 (06), 800-819, 2018.

[3] Emmanuel. N.O, Okoro.N, Ukonu.M.O, (2021) Beyond classroom- news room Gap: why do Nigerian students study journalism in the age of convergence? Media Practice and Education, 1-20, 2021

[4] Jackson.D, Thorsen. E, Reardon.S, (2020), Fantacy, pragmentism, and jouranalistic socialization: UK journalism studnets' aspirations and motivations, Journalism Practice 14 (1), 104- 124, 2020.

[5] McAdamas.K.C, Beasley.M.H, Zandberg.I, (2004) Women graduated (and men too) express reservations about journalism education, seeking equity for women in Journalism and Mass Communication Education:A 30 - year update, 315-330, 2004

[6] Price, John (2015) Where Are All the Women? Diversity, the Sports Media, and Sports Journalism Education. International Journal of Organizational Diversity, 14 (1). pp. 9-19. ISSN 2328-6261

[7] Rabe,L., 2006, Eve-olution: the status of female voice in South African media: Ecquid Novi: African Journalism Studies: Vol 23 , No 1.

[8] Sima Sharma, Irvin Weerackody, Narendra R. Panday, Sharif Al Mujahid \& A.B.M. Musa, 2016, Women and the Media in South Asia, Media Asia: Vol 14, No 4. Pages 218-227.

[9] Strong, C. (2007). Female journalists shun sports reporting: lack of opportunity versus lack of attractiveness, Communication Journal of New Zealand, He Kohinga Korero, 8:2: p7-18.

[10] Syed, A. 2002. Hybrid electric vehicles: Consumer misperceptions Retrieved August 2021, at (http://istocrates.berkeley.edu/ es196/projects/2002final/Syed.pdf) [Google Scholar]

Authors

First Author: Ms. K.G.L.A.N.S.Jayawardhana, B.A (Hons), MA (India), Senior Lecturer in Communication Studies, Department of Languages and Communication Studies, Trincomalee Campus of Eastern University, Sri Lanka.

Email: jayawardanak@esn.ac.lk

Second Author: Ms.S. Sriram, B.A (Hons), MPhil (UOK, Sri Lanka), Senior Lecturer in Communication Studies, Department of Languages and Communication Studies, Trincomalee Campus of Eastern University, Sri Lanka. Email: sivapriyas@esn.ac.lk

Corresponding Author: Ms. K.G.L.A.N.S.Jayawardhana, B.A (Hons), MA (India), Senior Lecturer In Communication Studies, Department of Languages and Communication Studies, Trincomalee Campus of Eastern University, Sri Lanka. Email: jayawardanak@esn.ac.lk, nisansala.jayawardhana@gmail.com T.P:+94 707535703 